\title{
Structural transect through Silurian turbidites of the Fredericton Belt southwest of Fredericton, New Brunswick: the role of the Fredericton Fault in late Iapetus convergence
}

\author{
Adrian F. Park and James Whitehead \\ Department of Geology, University of New Brunswick, P.O. Box 4400, Fredericton, NB, E3B 5A3 \\ apark@unb.ca jwhitehe@unb.ca
}

Date received:January 14, 2004 Date accepted:June 7, 2004

\begin{abstract}
Excavations along the $23 \mathrm{~km}$ stretch of the Longs Creek to Fredericton section of the new Trans-Canada Highway created new exposures affording a transect through part of the Fredericton Belt west of, and including, the Fredericton Fault. This transect lies entirely in the Burtts Corner beds of the Silurian Kingsclear Group, revealing a multi-deformation history. Earliest structural elements in the turbidites include a slaty cleavage $\left(\mathrm{S}_{1}\right)$ that is close to being beddingparallel in most places. No $\mathrm{F}_{1}$ fold closures have been identified, but small enclaves of inverted bedding imply that such structures exist but are of limited scale and restricted occurrence. The most conspicuous structures are upright to overturned, open to tight $\mathrm{F}_{2}$ folds with chevron profiles, a locally well-developed axial planar slaty cleavage $\left(\mathrm{S}_{2}\right)$ and a related crenulation lineation on $\mathrm{S}_{1}\left(\mathrm{~L}_{2}{ }_{2}\right)$. These folds have curvilinear hinge-lines that show an increase in curvilinearity toward the Fredericton Fault, coincident with a tightening of the interlimb angle. Lineations related to layer-parallel slip during $\mathrm{F}_{2}$ fold generation remain constant implying the changing geometry is a consequence of changing bulk strain rather than fold interference.

Post $-\mathrm{F}_{2}$ structures include a sparsely developed set of chevron folds with horizontal axial planes $\left(\mathrm{F}_{3}\right)$ and a poorly developed axial planar slaty cleavage $\left(\mathrm{S}_{3}\right)$. At least two sets of late kinks have also been noted.

Systematic variations in style and form of the $\mathrm{F}_{2}$ folds suggest a relationship with the precursor to the Fredericton Fault, implying a role for this structure in Acadian orogenic deformation starting out as a sub-horizontal detachment prior to rotation into its current vertical attitude. This low-angle dip-slip phase is related to the convergence of Avalonia* with the Miramichi terrane (the remains of the Ordovician Miramichi arc, incorporated into the Brunswick subduction complex by the mid-Silurian), and preceded the behaviour of the Fredericton Fault as an orogen-parallel strike-slip feature in later Acadian orogenesis.
\end{abstract}

\footnotetext{
* 'Avalonia' here refers to the composite terrane in southern New Brunswick consisting of Avalonia sensu stricto and a number of peri-Gondwanan terranes, see Barr and White $(1996,1999)$, or a southern terrane that is a composite of Avalonia and Ganderia (see for instance, van Staal et al. 2002). This contribution does not present any data allowing a choice between these models.
}

\section{RÉSUMÉ}

Des excavations le long d'un tronçon de 23 kilomètres de la section de la nouvelle transcanadienne menant de Long Creek à Fredericton ont créé de nouveaux affleurements représentant une coupe transversale d'une partie de la ceinture de Fredericton à l'ouest de la faille de Fredericton, inclusivement. Ce transect se trouve entièrement à l'intérieur des strates de Burtts Corner du groupe silurien de Kingsclear et témoigne d'un passé ayant comporté plusieurs déformations. Les éléments structuraux les plus précoces dans les turbidites comprennent une schistosité ardoiseuse $\left(\mathrm{S}_{1}\right)$ presque parallèle aux strates dans la majorité des endroits. Aucune fermeture de plis $F_{1}$ n'a été relevée, mais de petites enclaves de strates renversées laissent entendre que de telles structures existent mais qu'elles sont d'une échelle limitée et de fréquence réduite. Les structures les plus visibles comprennent des plis $\mathrm{F}_{2}$ ouverts à aigus, verticaux à renversés, aux profils en guirlandes, une schistosité ardoiseuse de plan axial bien développée $\left(\mathrm{S}_{2}\right)$ et une linéation à crénulation apparentée sur $\mathrm{S}_{1}\left(\mathrm{~L}_{2}^{1}\right)$. Ces plis possèdent des charnières curvilignes présentant une curvilinéarité accrue en direction de la faille de Fredericton; le phénomène correspond à un resserrement de l'angle inter-flancs. La linéation reliée au plissement parallèle aux couches pendant la production du pli $\mathrm{F}_{2}$ demeure constante, ce qui laisse supposer que la géométrie changeante est due à la déformation générale changeante plutôt qu'à l'interférence de plis.

Les structures ultérieures à $\mathrm{F}_{2}$ comprennent un ensemble peu développé de plis en guirlandes à plans axiaux 
horizontaux $\left(\mathrm{F}_{3}\right)$ et une schistosité ardoiseuse de plan axial faiblement développée $\left(\mathrm{S}_{3}\right)$. Au moins deux ensembles de flexures tardives ont également été relevés.

Les variations systématiques du style et de la forme des plis $\mathrm{F}_{2}$ laissent supposer un rapport avec la structure ayant précédé la faille de Fredericton, laissant entendre que cette structure a joué un rôle dans la déformation de l'orogenèse acadienne en commençant comme détachement subhorizontal avant sa rotation dans sa position verticale actuelle. Cette phase de rejet incliné à angle peu prononcé est apparentée à la convergence d'Avalonia* avec le terrane de Miramichi (vestiges de l'arc ordovicien de Miramichi, incorporés dans le complexe de subduction de Brunswick vers le milieu du Silurien) et a précédé le comportement de la faille de Fredericton qui est devenu un décrochement parallèle à l'orogène vers la fin de l'orogenèse acadienne.

\begin{abstract}
* Le terme «Avalonia» désigne ici le terrane composite du Sud du Nouveau-Brunswick constitué d'Avalonia au sens strict et d'un certain nombre de terranes périgondwaniens (voir Barr et White, 1996, 1999), ou un terrane méridional composé d'Avalonia et de Ganderia (voir par exemple van Staal et coll., 2002). La présente contribution ne fournit aucune donnée permettant un choix entre ces modèles.
\end{abstract}

[Traduit par la rédaction.]

\section{INTRODUCTION}

Throughout the Canadian and New England Appalachians orogen-parallel strike-slip faults and ductile shear zones show evidence of repeated reactivation (e.g., Goldstein 1989; Mosher and Berryhill 1991; Park et al. 1994; Ludman et al. 1999). For many of these structures, their initial geometry and kinematic significance is obscured by later movements, although some evidently originated as sutures between accreting tectonostratigraphic terranes during Iapetus Ocean closure (Ludman 1981, 1986; Fyffe and Fricker 1987; van Staal et al. 1998). New road cuttings and excavation during the construction of a new branch of the Trans-Canada Highway (TCH) south of Fredericton, New Brunswick, between March 1998 and February 2000 created both temporary and permanent outcrops in the Silurian and Carboniferous (Mississippian and Pennsylvanian) rocks of the area (Figs 1,2). The new TCH also crosses the trace of the regionally significant Fredericton Fault (the northernmost segment of the Norumbega Fault system of Maine and New England; Ludman and West 1999). This contribution concerns a structural transect through the Silurian rocks of the Fredericton Belt up to the Fredericton Fault (Fig. 2). The transect runs from Longs Creek, $20 \mathrm{~km}$ west of Fredericton, to Deerwood Drive, $5 \mathrm{~km}$ southwest of the city (Fig. 2), and includes a $3 \mathrm{~km}$ across-strike section through the Silurian Kingsclear Group up to the Fredericton Fault. In this transect, the geometry of early deformation structures (Acadian) sheds some light on the kinematic evolution of the Fredericton Fault.

\section{GEOLOGICAL SETTING}

The outcrop of Silurian rocks in the Fredericton area defines the Fredericton Trough (McKerrow and Ziegler 1971) or Fredericton Belt (Fyffe 1995), a coherent tract of turbidites lying between the Miramichi Highlands to the northwest and the St. Croix Highlands to the southeast (Fig. 1). This belt straddles the Fredericton Fault (Fig. 2). Freeze (1936) included all these sedimentary rocks in the Kingsclear Group, and following the proposal of various subdivisions, Fyffe (1995) recom- mended that the original definition be retained. Subdivision of the Kingsclear Group is primarily lithostratigraphic: thus east of the Fredericton Fault the Flume Ridge Formation and Digdeguash Formation are the lateral equivalent of the Kingsclear Group to the west (Fyffe and Riva 2001). Of the four sub-divisions of the Kingsclear Group west of the Fredericton Fault, viz: (from oldest to youngest) Hayes Brook beds, Cross Creek beds, Taxis River beds and Burtts Corner beds, only the youngest occurs in this transect.

Biostratigraphic data for the Kingsclear Group are scarce, but the Burtts Corner beds range at least between the Cyrtograptus linnarssoni Zone and Monograptus nilsonni Zone, indicating a Wenlock to early Ludlow age (Cumming 1966, Anderson 1970, Berry and Boucot 1970, Gordon 1973). These data constrain the deposition of the Burtts Corner beds to the interval 428-419 Ma, with the lower subdivisions of the Kingsclear Group deposited prior to $428 \mathrm{Ma}$, and the oldest possibly during the Ordovician (Tucker and McKerrow 1995; Ludman et al. 1999).

The Burtts Corner beds are turbidites, and both complete and incomplete Bouma cycles are present in this transect. Lithologies range from medium to thickly bedded lithic wacke (beds 1 to $10 \mathrm{~m}$ thick), locally containing pebbles, through laminated fine sandstone and siltstone (with beds 0.2 to 1.0 $\mathrm{m}$ thick), to shale and mudstone, some of which are carbonaceous. Most units in this transect are carbonate-poor, a general feature of the Burtts Corner beds (Wake 1984), but a few thin carbonate layers (calcite) have been noted, and some carbonaceous mudstone contains layers of siderite-pyrite ironstone. The calcite layers are highly recrystallized with ubiquitous bedding-parallel stylolites (Fig. 3a), and it is not clear whether they represent original carbonate beds or early, bedding-parallel veins. They are crenulated by the earliest foliation. The wacke units have abundant flute casts and tool marks along their base (Fig. 3b). These features as well as washouts, channels forms, tabular and trough cross-bedding, and ripples in the finer sandstone beds, permit reliable determination of way-up throughout the transect.

The Fredericton Fault is a segment of a regionally significant structure, the Norumbega Fault zone of New England, traceable at outcrop and geophysically from the Gulf of St. 


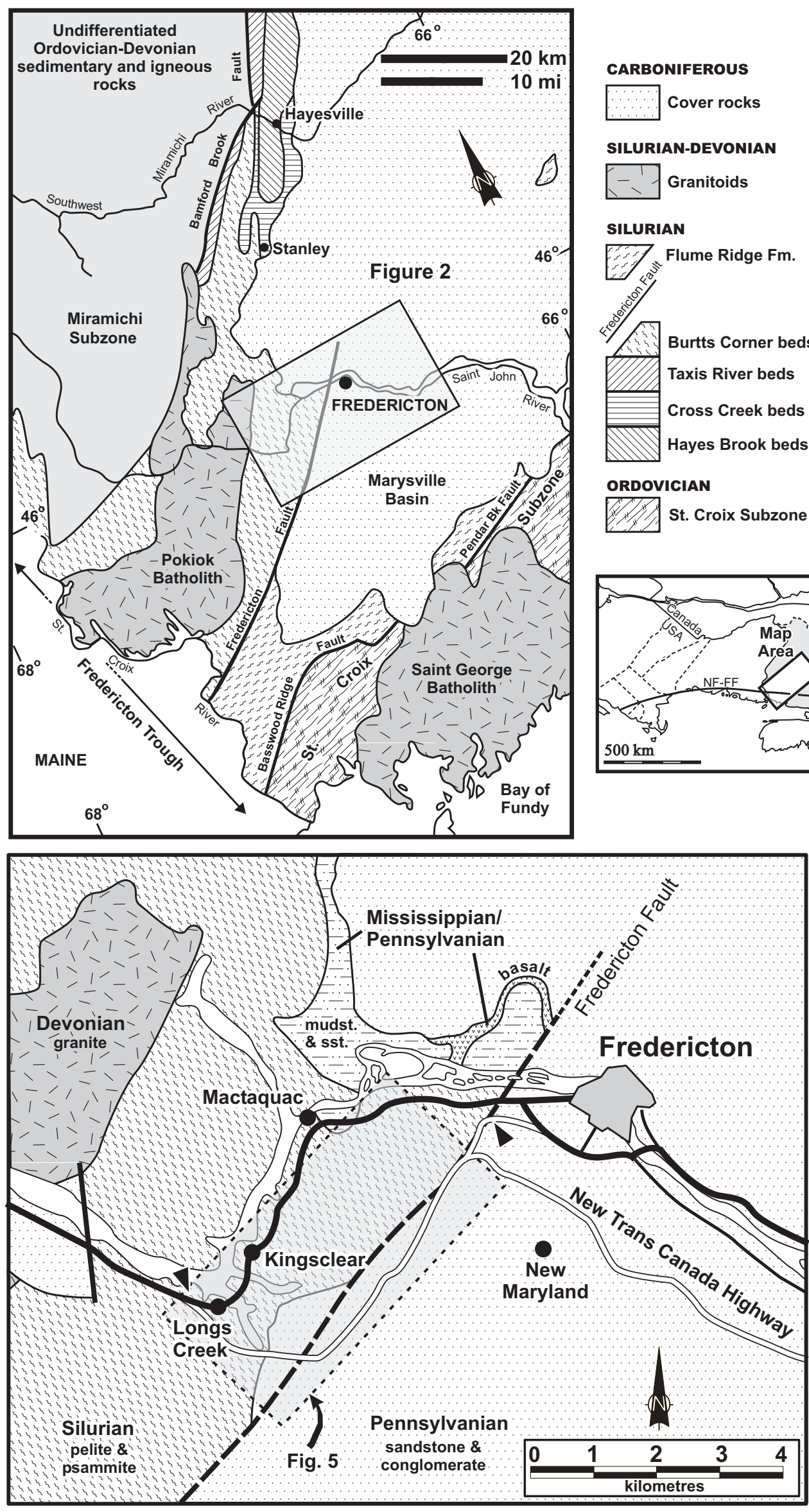

Fig. 1 Outline geological map of the Fredericton area, southern New Brunswick, indicating the position of the Fredericton Fault in relation to Silurian sedimentary sequences, Carboniferous cover and major Paleozoic plutons (after Fyffe 1995); inset shows relationship of the area covered to the Norumbega - Fredericton fault system (NF-FF on map) through New Brunswick and Maine, after Ludman and West (1999).

\section{ORDOVICIAN}

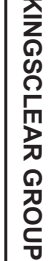

Fig. 2 Detailed geological map of the area SW of Fredericton traversed by the new Trans-Canada Highway (position indicated). Geology is based on Freeze (1936). 

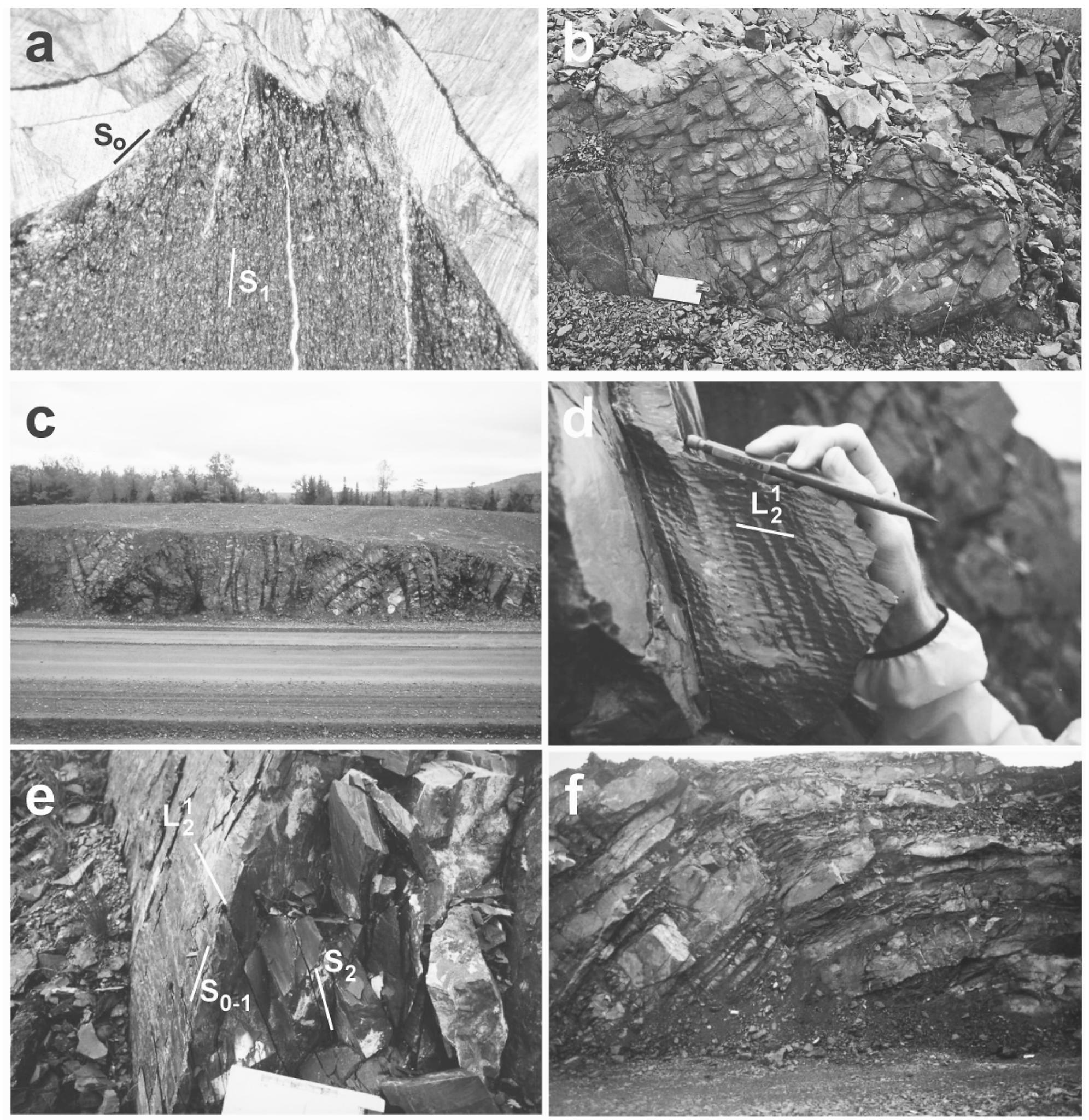

Fig. 3 (a) Micrograph of $S_{1}$ cleavage at high angle to bedding-parallel calcite vein in $F_{1}$ fold hinge. The black styolite is parallel to $S_{0}$. Burtts Corner beds, Deerwood Drive (see Fig. 4 for location of this downward facing antiform); crossed Nicols. (b) Flute-casts modified by layer-parallel slip, Burtts Corner beds, north side of cutting, west of Longs Creek. (c) Chevron style folds, $F_{2}$, in Burtts Corner beds, south of Longs Creek, central reservation in TCH looking south. (d) Crenulations on bedding $\left(\mathrm{S}_{0}\right)$ in shaly unit of Burtts Corner beds. (e) Bedding cleavage $\left(S_{0}\right.$ and $\left.S_{2}\right)$ relationship in Burtts Corner beds, generating the $L_{1 / 2}$ intersection lineation $\left(S_{1}\right.$ is bedding-parallel here). South of Longs Creek. (f) Small faults as accommodation structures in an $\mathrm{F}_{2}$ fold with thick, coarse sandy units in the Burtts Corner beds, south of Longs Creek, north side of TCH looking north. 


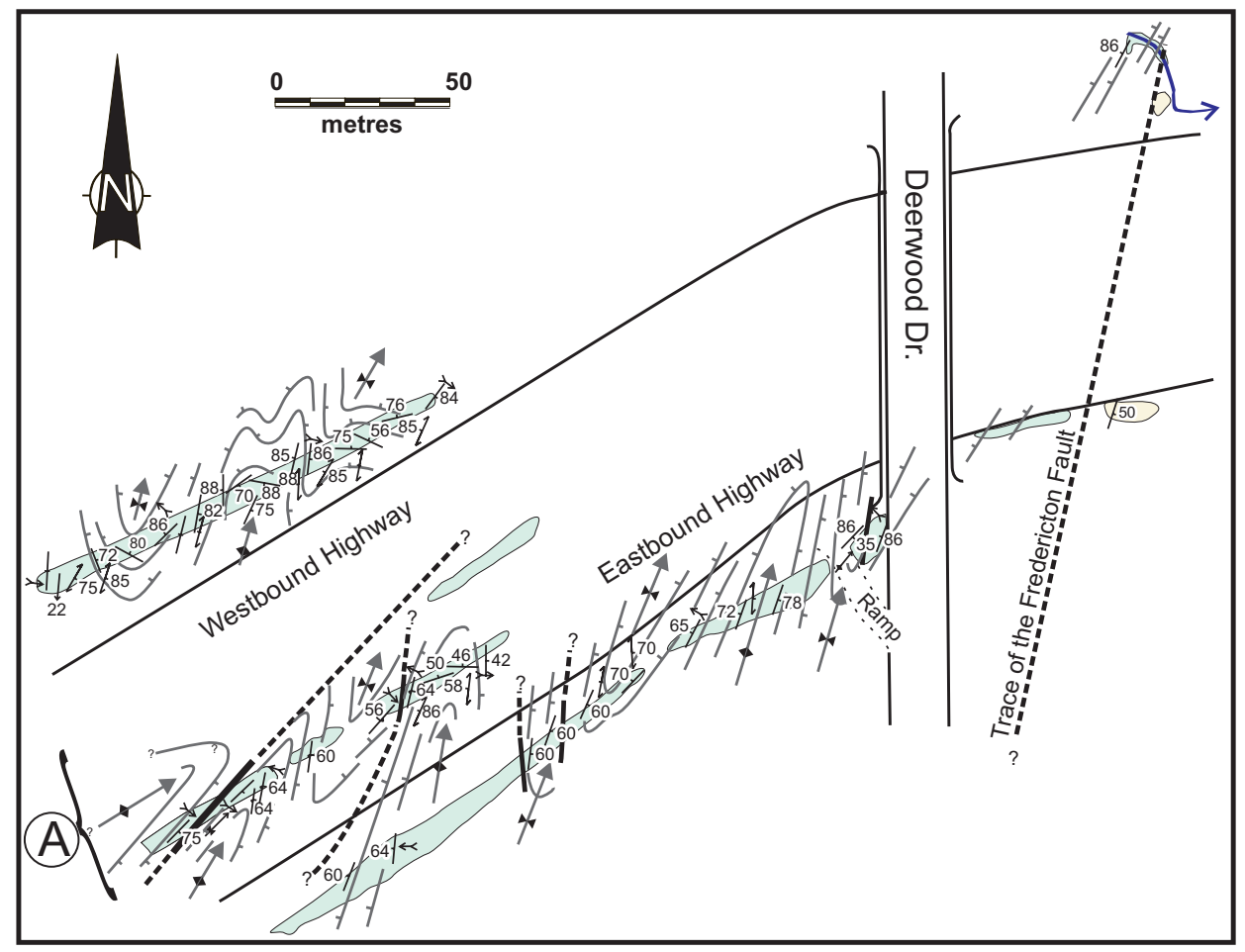

Lawrence to Long Island Sound (Stewart and Wones 1974; Durling and Marillier 1990; Bothner and Hussey 1999; Goldstein and Hepburn 1999; Ludman and West. 1999). It is one of several orogen-parallel structures traversing the New Brunswick part of the Appalachian orogen. Most of these features, some of which originated as terrane boundaries, share a complex history of reactivation as both strike-slip and dip-slip structures through the upper Paleozoic and early Mesozoic. Along its outcrop length the Fredericton-Norumbega Fault zone has accommodated strike-slip motion (Acadian - early to mid-Devonian), dip-slip motion during basin formation (Mississippian and Pennsylvanian), and late Mesozoic reactivation (Ludman et al. 1999). Prior to the mid-Devonian, displacement was predominantly strike-slip and minor displacement of the margins of mid-Devonian plutons in Maine suggests mainly dip-slip activity since that time (Wones 1984; Fyffe 1995; Mosher and Berryhill, 1991; Ludman et al. 1999). For all this complexity along its outcrop length, in New Brunswick the Norumbega-Fredericton fault zone is completely contained within the rocks of the Fredericton Belt (Ludman and West 1999). This characteristic implies that locally this fault is not a terrane boundary, but that its earliest history was linked to the structural evolution of the Fredericton Belt.

The rocks of the Fredericton Belt, distal to the thermal aureoles of local plutons are also metamorphosed, but the grade is sub-greenschist, and fossiliferous beds, rare on account of the paleoenvironmental facies, show little recrystallization. For simplicity and clarity sedimentary rock nomenclature is used throughout this account.
Fig. 4 Form surface map of bedding and folds in the Kingsclear Group where Deerwood Drive crosses the new Trans-Canada Highway. Note especially the segment in the SW corner bounded by two small faults containing a downward facing antiform indicating the presence of pre$F_{2}$ folds whose closures are not seen. Rocks exposed in the median during construction (marked A) have since been removed or buried.

\section{STRUCTURES}

\section{Earliest structures}

The earliest structural element developed in the Burtts Corner beds in this transect is a ubiquitous slaty cleavage $\left(\mathrm{S}_{1}\right)$ in the more argillaceous lithologies. With one important exception, this cleavage is bedding-parallel or sub-parallel with an angle to bedding of less than $5^{\circ}$. In one fault-bounded tract at the eastern end of the transect, near Deerwood Drive, a high cleavage to bedding angle is preserved (Fig. 3a) and significantly, this is the one location where bedding is completely inverted in a downward-facing antiform (Fig. 4). Elsewhere, minor rootless folds have been identified, but their relationship to the $S_{1}$ cleavage is ambiguous, and whether they are transposed $\mathrm{F}_{1}$ minor folds or modified sedimentary structures cannot be resolved. The presence of inverted bedding near Deerwood Drive implies that a large scale $F_{1}$ fold is present here, but no $\mathrm{F}_{1}$ closure is exposed or preserved (Fig. 4).

\section{$F_{2}$ and $S_{2}$ structures}

The structural elements that dominate the outcrops along the new TCH (as well as the old TCH, Fig. 5) are $\mathrm{F}_{2}$ folds. These folds are open to tight with a wavelength between 10 and $50 \mathrm{~m}$, an amplitude of the same order, and upright to slightly overturned axial planes (Fig. 3c). Axes commonly trend NE-SW, plunging both to the NE and SW, with an average attitude close to horizontal. The steepest plunges are greater than $60^{\circ}$ (both $\mathrm{NE}$ and $\mathrm{SW}$ ), though $0^{\circ}$ to 25 or $30^{\circ}$ is more typical. Interlimb 


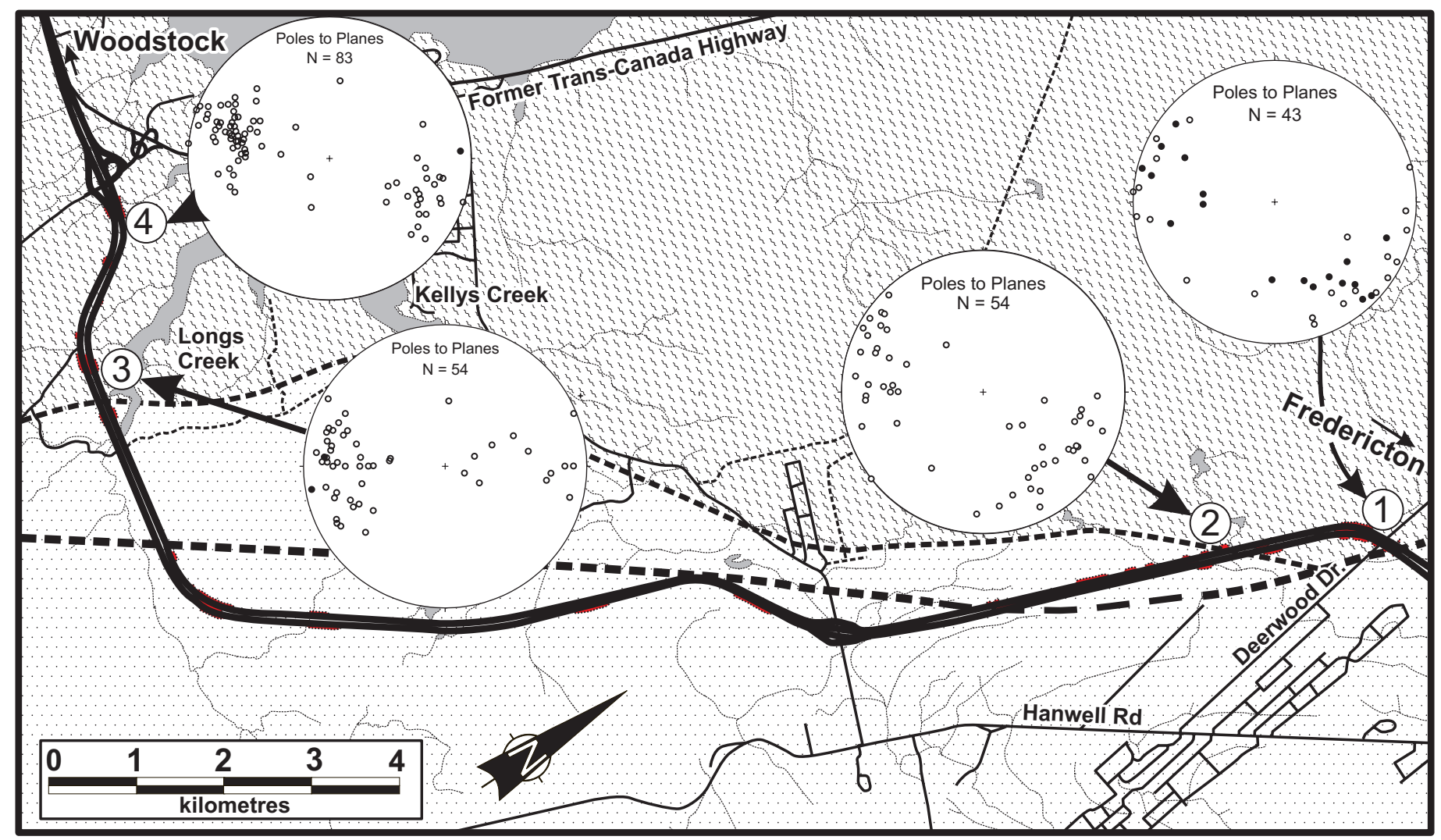

Fig. 5 Map of the geology along the new Trans-Canada Highway between Woolastook and Fredericton, showing the trace of the Fredericton Fault (coarse dash) and the sub-Carboniferous angular unconformity (fine dash). Stereonets (equal area) illustrate the orientation of bedding $\left(\mathrm{S}_{0}\right)$ in the Silurian Kingsclear Group (diagonal legend) in the four sections of the traverse. Numbers of the stereonets correspond to those used in Fig. 6.

angles range from over $100^{\circ}$ to as little as $5-10^{\circ}$. Where thickly bedded lithic wackes are present, fold styles are extremely disharmonic and disrupted by accommodation faults, but in argillaceous sequences with thinner or laminated sandstone and siltstone the fold profiles are generally chevron (Fig. 3c).

An axial planar cleavage $\left(\mathrm{S}_{2}\right)$ is penetrative in argillaceous units, where it is a slaty cleavage (lithons $<1 \mathrm{~mm}$ wide, Fig. $3 \mathrm{~d}$ ). In coarser-grained rock types it is more spaced or represented by sub-parallel fracture sets or regular accommodation faults. The intersection of $S_{2}$ with $S_{1}$ means the $\mathrm{L}_{2}^{1}$ intersection lineation is ubiquitous, almost a pencil-fabric in some places, and a crenulation lineation $\left(\mathrm{L}_{2}\right)$ is also widespread (Fig. 3d, e).

Slickensides on bedding or a finer lineation related to layerparallel slip have a consistent geometric relationship to the $\mathrm{F}_{2}$ folds (Fig. 5). They are generally steep, close to maintaining a down-dip orientation. This combined with the variations in $\mathrm{F}_{2}$ fold axes plunge and trend indicates the curvilinearity of the hinge-lines to these folds is a primary feature and not a fold interference pattern (Fig. 5).

The variation in all interlimb angles and hinge line curvilinearity appears to have little consistency, largely because one source of 'noise' is the effect of lithology on fold style. This effect is strongest in those turbidite sections containing thickbedded coarse to pebble-bearing lithic wacke, such as the east end of the cuttings at Longs Creek and immediately east of the intersection with the old TCH at Woolastook (Fig. 3f). Here the fold profiles are dominated by accommodation structures and become strongly disharmonic. However, if fold styles are compared in similar lithologies through the section, especially in the thinly bedded turbidites dominated by shale-mudstone and fine-grained sandstone or siltstone layers, a distinct trend is apparent (Fig. 6). Interlimb angles for these $\mathrm{F}_{2}$ folds decrease from the Longs Creek area $\left(90-120^{\circ}\right)$ toward Deerwood Drive $\left(5-15^{\circ}\right)$ and the Fredericton Fault, and curvilinearity of the hinge lines becomes more pronounced in the same direction (Figs 6,7). At the same time the layer-slip lineation sustains a constant relationship, presumably orientated with respect to relatively fixed pinning points along the fold hinge during flexural slip (e.g., Tanner 1989, 1992). Hinge collapse is observed in two settings: as the interlimb angle of all folds decreases near the Fredericton Fault or where thick wacke units render folds disharmonic anywhere in the transect.

\section{Post $\mathrm{F}_{2}$ structures}

One set of folds $\left(\mathrm{F}_{3}\right)$ and at least two sets of kink bands and kink-folds are apparent in the turbidites of this transect. The kinks are a widespread feature in this area (Fyffe 1995). The $F_{3}$ 

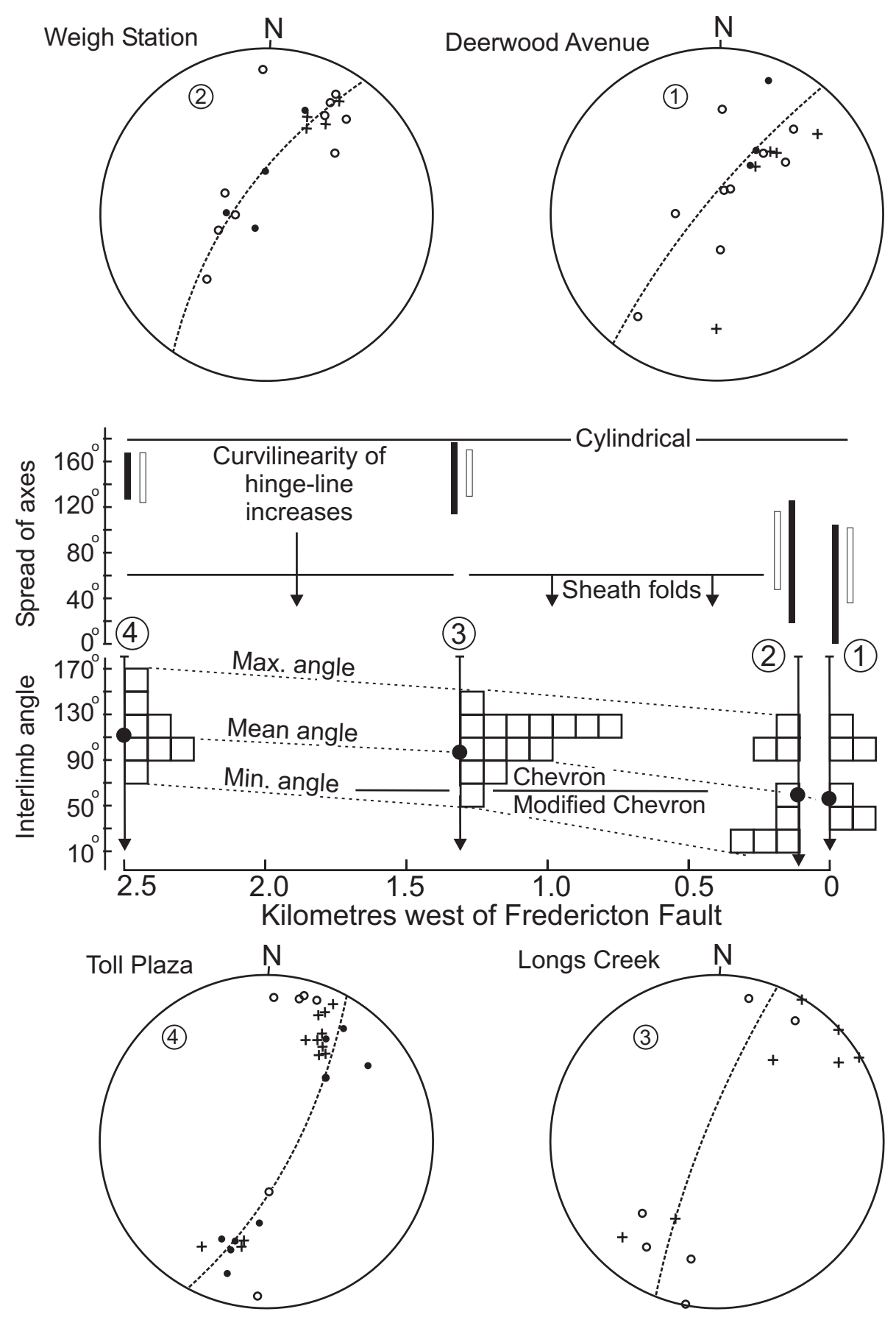

Fig. 6 Summary of $\mathrm{F}_{2}$ fold geometries along the new TCH transect and their relationship to the Fredericton Fault (right hand edge of the diagram). Data are from folds in thinly bedded turbidites with no massive sandstone layers. Plotted are interlimb angles and degree of spread of axis measurements along the hinge (curvilinearity). As interlimb angles decrease the degree of curvilinearity increases. The four histograms indicate number of measurements at each locality. Key: filled circles are $\mathrm{F}_{2}$ axes (measured; open circles are $\mathrm{F}_{2}$ axes (calculated); crosses are $\mathrm{L}_{2}^{1}$ and $\mathrm{L}_{2}^{0}$ intersection lineations. For numbered localities see Fig. 5. 


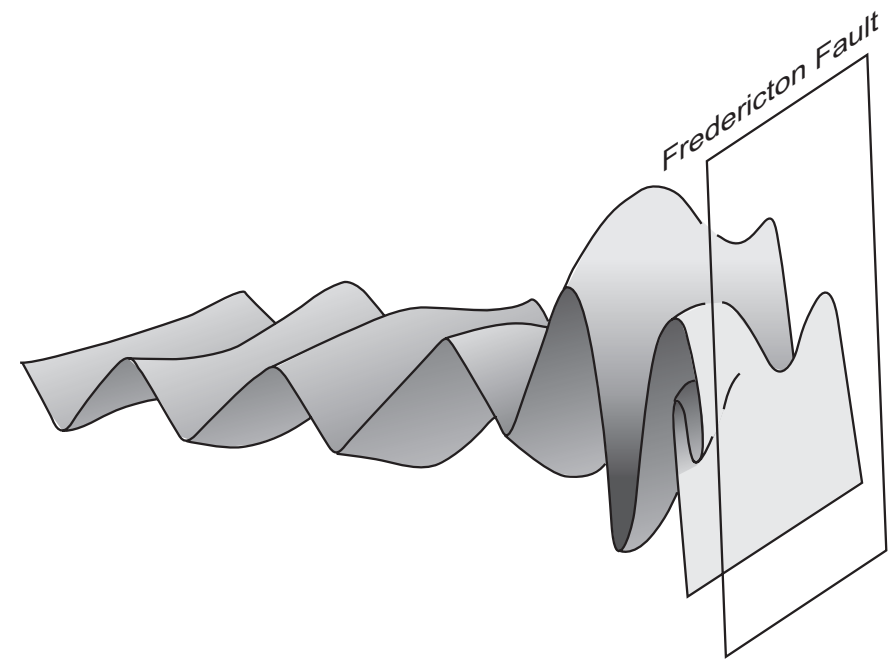

Fig. 7 Sketch summarizing the geometry of $\mathrm{F}_{2}$ folds in relation to the Fredericton Fault - curvilinearity of the hinge lines increases as interlimb angles decrease toward the fault. The only clear example of the effects of $F_{1}$ folding occurs adjacent to the outcrop of the fault.

folds are sparsely developed and consistent in their orientation, but their relationship to the kinks cannot be established along this transect.

The $\mathrm{F}_{3}$ folds have a chevron profile and sub-horizontal axial plane. A poorly developed cleavage, both a crenulation and spaced fractures (1-2 $\mathrm{mm}$ spacing) have been seen in mudstone and shale. Too few examples of these folds have been observed to draw any conclusions about regional patterns other than to note that horizontal faults and open folds with sub-horizontal axial planes are also seen in Mississippian-Pennsylvanian sedimentary rocks at Longs Creek. However, the best examples seen in this transect occur close to the Fredericton Fault where $\mathrm{F}_{2}$ folds are tight and display hinge collapse, suggesting a genetic relationship (e.g., Ramsay 1974).

\section{Timing of deformation history}

The $S_{1}$ and $S_{2}$ fabrics seen in this transect of the Kingsclear Group are also present regionally and are found recrystallized in the thermal aureole of the Pokiok batholith to the west (Fig. 1; Caron 1996) indicating that deformation up to the production of $\mathrm{F}_{2}$ folds predated the early Devonian emplacement of this granitoid. Similar relationships are observed in the margins of the Deblois and Bottle Lake plutons $100 \mathrm{~km}$ to the southwest in Maine. These plutons are dated at 380 \pm 5 and $384 \pm 5 \mathrm{Ma}$ and are thus mid-Devonian (Ludman et al. 1999). Fossil evidence indicates that the youngest parts of the Burtts Corner beds are of Ludlow age at least (428-419 Ma, Fyffe 1995; Tucker and McKerrow 1995). The deformation history spanning deposition to $\mathrm{S}_{1}-\mathrm{F}_{2}\left(\mathrm{~S}_{2}\right)$ deformation is thus constrained to late Silurian - early Devonian time, representing the Acadian orogeny of the Maritime Appalachian orogen. This result is consistent with the detailed chronology elucidated by Ludman et al. (1999) in eastern Maine (100-120 $\mathrm{km}$ southwest of this area), where the Deblois and Bottle Lake plutons interact with the Norumbega fault system. Ludman et al. (1999) recognized the first phase of strike-slip displacement as imposing a foliation on these 384 and 380 Ma plutons, and this phase of deformation was dated at $376 \pm 5 \mathrm{Ma}$. Upright folding in the Fredericton Belt in that area predates all the strike-slip displacement (Ludman et al. 1999).

Later deformation features, such as sparsely developed $\mathrm{F}_{3}$ folds and kink bands are harder to constrain, but $\mathrm{F}_{3}$-like folds in Mississippian- Pennsylvanian sedimentary rocks at Longs Creek may have Alleghanian affinities. The local data set is not complete enough to attempt any meaningful correlations.

\section{SIGNIFICANCE OF DEFORMATION IN THE FREDERICTON BELT}

Interpretation of the deformation in the Fredericton Belt addresses a number of important issues in the evolution of the Maritime Appalachians. The Fredericton Belt (or Trough) was recognized as an important feature in the early CaledonianAppalachian orogen models (McKerrow and Ziegler 1971). Recent models suggest that the belt was an arc-trench gap or fore-deep basin oceanward of the Miramichi Highlands, receiving debris from this terrane as the arc it represents accreted to North America and then underwent uplift (van Staal et al. 1998, 2002). The Kingsclear Group (and Flume Ridge and Digdeguash Formations) are perceived as clastic debris wedges prograding eastward as the eastern margin of the Miramichi arc over-rode the basin and its own debris. Deformation in such a model would rapidly follow the onset of deposition and the two would proceed together as the basin closed, and then relate to the collision of the Miramichi arc terrane with the leading edge of Avalonia or Ganderia, whichever is represented by the St. Croix terrane (Williams 1995; van Staal et al. 1996). The Fredericton Belt, therefore, represents sedimentation in a remnant of Iapetus Ocean (either within Ganderia, or between it and Avalonia, depending on the attribution of the St. Croix terrane; see Barr et al. 2002 for full discussion), and the collision was finally sutured along the Pendar Brook and Basswood Ridge faults (Fig. 1; van Staal et al. 1998). As the Fredericton Fault (and by correlation, the Norumbega Fault zone) is contained within the Fredericton Belt, by implication this fault is not a terrane suturing structure here, but relates to the internal evolution of the Fredericton Belt (Fig. 8).

After suturing, the terrane collage readjusted along orogenparallel structures such as the Fredericton-Norumbega Fault (now a strike-slip boundary) and others such as the Belleisle and Kennebecasis faults to the southeast (Nance 1987; Park et al. 1994). Most of these regional strike-slip structures originated as features related to collision and suturing (or terrane docking) before evolving into orogen-parallel strike-slip zones, and this transition was largely completed by the time mid-Devonian plutons were emplaced in New Brunswick and Maine (Wones 1984; Ludman et al. 1999). Some of these 
faults underwent subsequent reactivation during Alleghanian movements or final docking of the Meguma terrane, and some reactivated during opening of the North Atlantic Ocean (Plint and van de Poll 1984; Ludman et al. 1999).

Data from this structural transect can address two aspects of this regional model: 1 . The significance of deformation in the Fredericton Belt to the Acadian collision of Avalonia with the Miramichi arc. 2. The relationship of this deformation to the nature and age of the Fredericton Fault.

In his seminal study of chevron fold mechanisms in regional deformation, Ramsay (1974) identified a limit to purely flexural-slip (layer-parallel slip) defined by interlimb angle. Once interlimb angles tighten below ca. $60^{\circ}$ the simple pattern of open, upright folds with an axial planar cleavage is replaced, or superimposed by, either hinge collapse and refolding with a second cleavage developing at a high angle to the first, or by a wholesale rotation of segments of the fold train.

In this structural transect, chevron folds commonly tighten through the critical angle without local refolding or development of a second cleavage according to the Ramsay (1974) model (though two isolated examples of $F_{3}$ folds near Deerwood Drive may be of this nature). Tightening is furthermore, not a general feature of the transect but becomes more pronounced toward the Fredericton Fault, just as the same folds display more strongly curvilinear hinge lines (Figs $6,7)$. Rotation of this segment of the fold train is the logical alternative, such that $F_{2}$ fold axial planes move close to the orientation of earlier bedding-parallel or sub-parallel structures as bulk strain increases. This tightening and increase in curvilinearity of hinge lines indicates increasing bulk strain towards the Fredericton Fault which occurred within the same geometric framework as the initial layer-parallel flexural slip. Coincidentally, the only trace of a pre- $\mathrm{F}_{2}$ fold phase occurs close to the same fault. If this fault originated as a low-angle detachment or thrust related to $\mathrm{F}_{2}$ folding, this is precisely the location in which refolding is expected to have developed due to progressive non-coaxial deformation (Fig. 8; Williams and Zwart 1977; Park 1995).

A model relating $F_{2}$ (and $F_{1}$ ) folds to the initial Fredericton Fault, a low-angle detachment with dip-slip motion, explains the increase in bulk strain toward the present fault. It implies that both the Fredericton Fault and the Pendar Brook and Basswood Ridge faults to the southeast, initiated as thrusts carrying sedimentary rocks of the Fredericton Belt over the leading edge of the composite terrane to the south, including Avalonia (Barr and White 1996, 1999; Fig. 8a, b). The cover rocks to the St. Croix terrane, the Mascarene Group, would have lain in the footwall of such a structure, and they are indeed deformed in a similar manner (Fyffe et al. 1999). The northwest-dipping deep-crust reflectors identified by Durling and Marillier (1990) would relate to this phase of evolution. Isostatic readjustment during subsequent orogen collapse would then rotate these faults and their associated fold axial planes, to a steeper orientation (Fig. 8c). Large, early, low-angle dip-slip displacements are possible without the need for large vertical throws across these faults. Rotation to vertical during
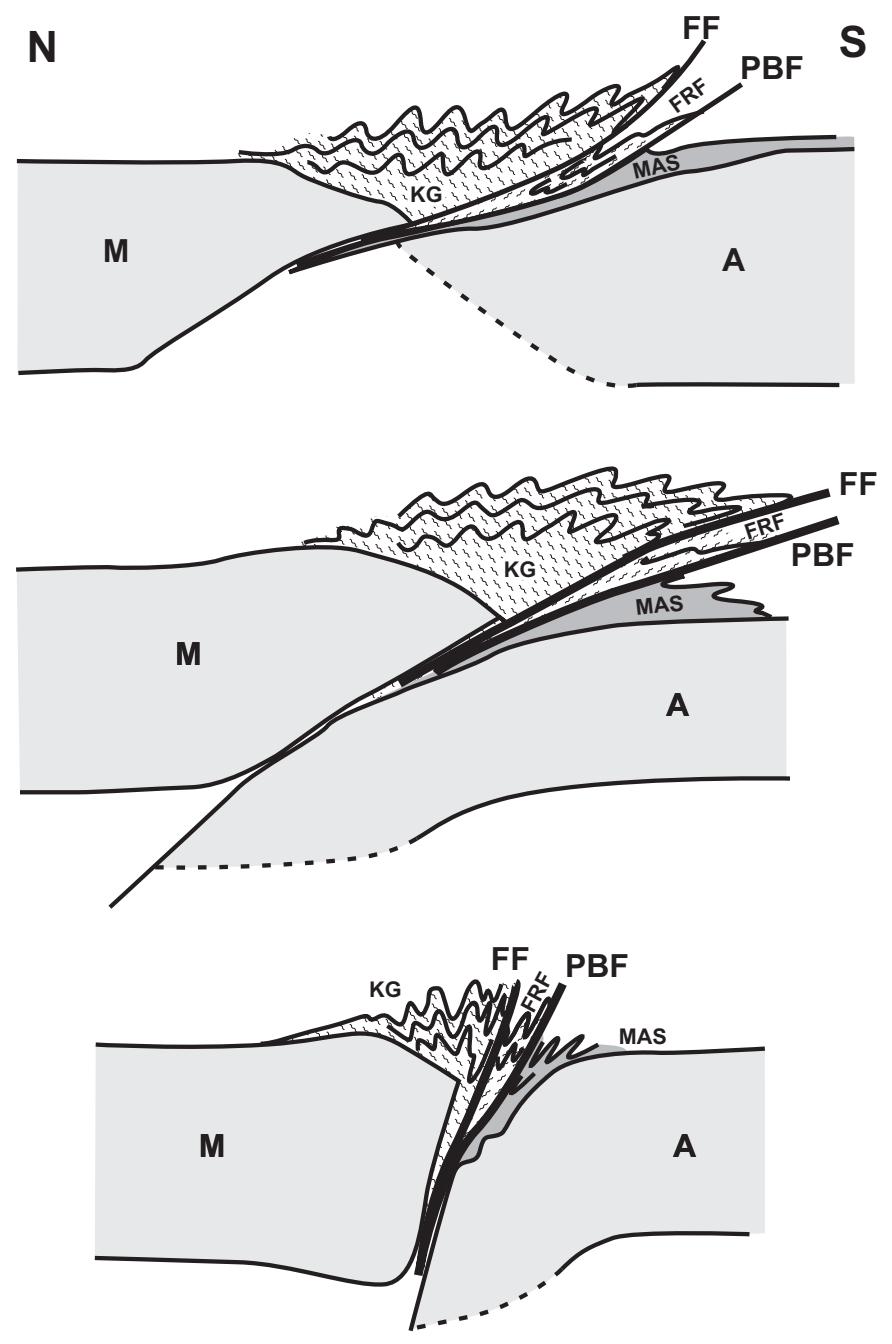

Fig. 8 Cartoon illustrating the evolution of the Fredericton Fault during late Iapetus convergence of the Avalon (or Ganderia/Avalonia) terrane (A) with the edge of North America (M, the Miramichi Highlands - Brunswick subduction complex of van Staal et al. 2002). (a) Initial collision of the two terranes with the sedimentary rocks of the Fredericton trough $(\mathrm{KG}=$ Kingsclear Group and FRF = Flume Ridge Formation) over-riding the leading edge of the Avalon (or composite Ganderia/Avalonia) terrane with its cover rocks of the Mascarene Group (MAS). The Fredericton Fault (FF) and Pendar Brook Fault (PBF) are early thrust-faults. (b) Edge of North America (M) overrides Avalonian (or composite Ganderia/Avalonia) rocks. $F_{2}$ fold axes in the Kingsclear Group rotate toward the Fredericton Fault. (c) Orogen-collapse rotates the Fredericton Fault (and Pendar Brook Fault) and $\mathrm{F}_{2}$ fold axes back towards vertical. Motion of the Fredericton Fault changes from predominantly dip-slip to strike-slip.

orogen collapse may then have produced the pattern of steeply dipping faults and tight $\mathrm{F}_{2}$ folds with near-vertical axial planes seen in this transect near the Fredericton Fault, and reported from the Mascarene Group and the Pendar Brook Fault (Fig. 8; Fyffe et al. 1999). Subsequent strike-slip motion would then 
represent adjustments in the accreted collage. Such readjustments would eventually occur through to the late Mesozoic opening of the North Atlantic, consistent with the interpreted age of those motions of the Norumbega Fault that appear to offset the Moho (itself only locally defined in the late Mesozoic - see Doll et al. 1996). Such a model is also consistent with (but in the absence of detailed biostratigraphy does not critically test) the foredeep/foreland wedge model for the Fredericton Belt proposed by van Staal and de Roo (1995).

\section{CONCLUSIONS}

1. The transition from convergence across the closing Fredericton Trough to strike-slip adjustments along orogenparallel faults occurred in the time interval from Ludlow to mid-Devonian time. Structures up to the $\mathrm{F}_{2}$ folds were generated during this time interval in the Fredericton Belt.

2. Bulk strain in this transect suggests a direct relationship between fold-style and the Fredericton Fault. This may reflect the generation of the $\mathrm{F}_{1}-\mathrm{F}_{2}$ structures to a precursor to the Fredericton Fault which was a low-angle detachment.

3. The Fredericton Fault may have originated as a thrust within the sedimentary fill of the Fredericton Trough during convergence with, then overthrusting onto, the leading edge of the southern terrane (which may be Avalonia or a Ganderia-Avalonia composite, a distinction this contribution cannot critically assess).

4. Rotation of the Fredericton Fault and its related folds to a near-vertical attitude was accompanied by orogen-collapse as this fault changed to a strike-slip, orogen-parallel adjustment structure.

\section{ACKNOWLEDGEMENTS}

We would like to acknowledge logistical support from New Brunswick Department of Natural Resources during field work, and thank Maritime Road Development Corporation for granting access to their construction sites along the new Trans-Canada Highway. Cees van Staal and Les Fyffe are also thanked for their thorough and useful reviews.

\section{REFERENCES}

Anderson, F.D. 1970. Geology of McKendrick map area, New Brunswick. Geological Survey of Canada Paper 69-12, $16 \mathrm{p}$.

BARr, S.M., \& White, C.E. 1996. Contrasts in late Precambrian - early Paleozoic tectonothermal history between Avalon Composite Terrane sensu stricto and other peri-Gondwa- nan terranes in southern New Brunswick and Cape Breton Island, Canada. In Avalonian and related peri-Gondwanan terranes of the Circum-North Atlantic. Edited by R.D. Nance and M.D. Thompson. Geological Society of America Special Paper 304, pp. 95-108.

BARR, S.M., \& WhITE, C.E. 1999. Field relationships, petrology and structure of Neoproterozoic rocks in the Caledonian Highlands, southern New Brunswick. Geological Survey of Canada Bulletin 530, $101 \mathrm{p}$.

Barr, S.M., White, C.E. \& Miller, B.V. 2002. The Kingston terrane, southern New Brunswick, Canada: evidence for a Silurian volcanic arc. Geological Society of America Bulletin, 114, pp. 964-982.

BERRY, W.B.N., \& Boucot, A.J. 1970. Correlation of the North American Silurian rocks. Geological Society of America Special Paper 102, 289 p. (pp. 53-71, 203, 232).

BothNeR, W.A., \& Hussey, A.M. 1999. Norumbega connections: Casco Bay, Maine to Massachusetts? In Norumbega Fault System of the Northern Appalachians. Edited by A. Ludman and D.P. West. Geological Society of America Special Paper 331, pp. 59-72.

Caron, A. 1996. Geology of the Pokiok batholith aureole, with emphasis on the Lake George Mine, York County, New Brunswick. New Brunswick Department of Natural resources and Energy, Minerals and Energy Division Geoscience Report 94-2, 91 p.

Cumming, L.M. 1966. Report on graptolite from Mactaquac, New Brunswick, collected by D.A. Gordon, University of New Brunswick. Geological Survey of Canada, internal palaeontological report, $4 \mathrm{p}$.

Doll, W.E., Domoracki, W.J., Costain, J.K., Coruh, C., Ludman, A., \& Hopeck, J.T. 1996. Implications of a seismic reflection profile across a part of the Norumbega fault system, east-central Maine. Geology, 24, pp. 251-254.

Durling, P., \& Marillier, F. 1990. Structural trends and basement rock subdivisions in the western Gulf of St. Lawrence, Northern Appalachians. Atlantic Geology, 26, pp. 79-95.

FreEze, A.C. 1936. Geology of the Fredericton sheet, New Brunswick. M. Sc. Thesis, University of New Brunswick, Fredericton, New Brunswick, $62 \mathrm{p}$.

FyFFe, L.R. 1995. Fredericton belt. In Geology of the Appalachian-Caledonian Orogen in Canada and Greenland. Edited by H. Williams. Geological Survey of Canada, Geology of Canada 6, ch. 6, pp. 351-354.

FyFFE, L.R., \& Fricker, A. 1987. Tectonostratigraphic terrane analysis of New Brunswick. Maritime Sediments and Atlantic Geology, 23, pp. 113-123.

FyfFe, L.R. \& RIVA, J.F.V. 2001. Regional significance of graptolites from the Digdeguash Formation of southwestern New Brunswick. In Current Research 2000. Edited by B.M.W. Carroll. New Brunswick Department of Natural Resources and Energy, Minerals and Energy Division, Mineral Resource Report 2001-4, pp. 47-54.

Fyffe, L.R., Pickerill, R.K., \& STRINGer, P. 1999. Stratigraphy, sedimentology and structure of the Oak Bay and 
Waweig formations, Mascarene basin: implications for the paleotectonic evolution of southwestern New Brunswick. Atlantic Geology, 35, pp. 59-84.

Goldstein, A.G. 1989. Tectonic significance of multiple motions on terrane-bounding faults in the northern Appalachians. Geological Society of America Bulletin, 101, pp. 927-938.

Goldstein, A.G., \& Hepburn, J.C. 1999. Possible correlations of the Norumbega fault system with faults in southeastern New England. In Norumbega Fault System of the Northern Appalachians. Edited by A. Ludman and D.P. West. Geological Society of America Special Paper 331, pp. 73-84.

GoRDON, A.J. 1973. Silurian rocks of the Fredericton area. In Geology of New Brunswick, Field Guide to Excursions. Edited by N. Rast. New England Intercollegiate Geological Conference, University of New Brunswick, Fredericton, New Brunswick, pp. 125-131.

Ludman, A. 1981. Significance of transcurrent faulting in eastern Maine and location of the suture between Avalonia and North America. American Journal of Science, 281, pp. 463-483.

LUDMAN, A. 1986. Timing of terrane accretion in eastern and east-central Maine. Geology, 14, pp. 411-414.

Ludman, A., \& West, D.P. 1999. Preface. In Norumbega Fault System of the Northern Appalachians. Edited by A. Ludman and D.P. West. Geological Society of America Special Paper 331, pp. v-xii.

Ludman, A., Lanzirotti, A., Lux, D., \& Chunzeng, W. 1999. Constraints on timing and displacement of multiple shearing in the Norumbega fault system, eastern Maine. In Norumbega Fault System of the Northern Appalachians. Edited by A. Ludman and D.P. West. Geological Society of America Special Paper 331, pp. 179-194.

McKerrow, W.S., \& Ziegler, A.M. 1971. The Lower Silurian paleogeography of New Brunswick and adjacent area. Journal of Geology, 79, pp. 635-646.

Mosher, S., \& Berryhill, A.W. 1991. Structural analysis of progressive deformation within complex, transcurrent shear zone systems: southern Narragansett Bay, Rhode Island. Journal of Structural Geology, 13, pp. 557-578.

Nance, R.D. 1987. Model for the Precambrian evolution of the Avalon terrane in southern New Brunswick. Geology, 15, pp. 753-756.

PARK, A.F. 1996. Structural evolution of sulphide tectonites and their host rocks, Stratmat mine, New Brunswick. Canadian Journal of Earth Sciences, 33, pp. 472-492.

Park, A.F., Williams, P.F., Ralser, S., \& Leger, A. 1994. Geometry and kinematics of a major crustal shear zone segment in the Appalachians of southern New Brunswick. Canadian Journal of Earth Sciences, 31, pp. 1523-1535.

Plint, A.G., \& van de Poll, H.W. 1984. Structural and sedimentary history of the Quaco Head area, southern New Brunswick. Canadian Journal of Earth Sciences, 21, pp. 735-761.

RAMSAY, J.R. 1974. Development of chevron folds. Geological Society of America Bulletin, 85, pp. 1741-1754.
Stewart, D.B. \& Wones, D.R. 1974. Bedrock geology of the northern Penobscot Bay area. In Geology of east-central and north-central-Maine. Edited by P.H. Osberg. New England Intercollegiate Geological Conference Guidebook, 66, pp. 223-239.

TANNER, P.W.G. 1989. The flexural slip mechanism. Journal of Structural Geology, 11, pp. 635-655.

TANNER, P.W.G. 1992. Morphology and geometry of duplexes formed during flexural slip folding. Journal of Structural Geology, 14, pp. 1173-1192.

Tucker, R.D., \& McKerrow, W.S. 1995. Early Paleozoic chronology: a review in light of new U-Pb zircon ages from Newfoundland and Britain. Canadian Journal of Earth Sciences, 32, pp. 368-379.

van StaAl, C.R. AND De Roo, J.A. 1995. Mid-Palaeozoic tectonic evolution of the Appalachian Central Mobile Belt in northern New Brunswick, Canada: collision, extensional collapse, and dextral transpression. Geological Association of Canada Special Paper 41, pp. 367-389.

van Staal, C.R., Sullivan, R.W. and Whalen, J.B. 1996. Provenance and tectonic history of the Gander margin in the Caledonian/Appalachian orogen: implications for the origin and assembly of Avalonia. Geological Society of America Special Paper 304, pp. 347-367.

van StaAl, C.R., Dewey, J.F., Mac Niocall, C., \& McKerRow, W.S. 1998. The Cambrian-Silurian tectonic evolution of the northern Appalachian and British Caledonides: history of a complex, west and southwest Pacific-type segment of Iapetus. In Lyell: the Past is the Key to the Present. Edited by D.J. Blundell and A.C. Scott. Geological Society of London Special Publication 143, pp. 199-242.

van StaAl, Wilson, R.A., Rogers, N., FyfFe, L.R., Langton, J.P., McCutcheon, S.R., McNicoll, V. \& Ravenhurst, C.E. 2002. Geology and tectonic history of the Bathurst Supergroup, Bathurst Mining Camp, and its relationship to coeval rocks in southwestern New Brunswick and adjacent Maine - a synthesis. Economic Geology Monograph 11, pp. 1-28.

WAKE, C. 1984. Sedimentology and provenance of the Kingsclear Group turbidites of the Fredericton Trough, New Brunswick. B. Sc. Thesis, University of Ottawa, Ottawa, Ontario, 59 p.

Williams, H. 1995. Temporal and spatial divisions, Ch. 2. In Geology of the Appalachian-Caledonian orogen in Canada and Greenland. Edited by H. Williams. Geological Survey of Canada, Geology of Canada, 6, pp. 21-44.

Williams, P.F. \& ZWART, H. 1977. A model for the development of the Seve-Koli Caledonian nappe complex. In Energetics of Geological Processes, Edited by S.K. Saxena and S. Bhattacharji. Springer-Verlag, New York. pp. 171-187.

Wones, D.R. 1984. (editor) The Caledonides in the USA. Virginia Polytechnic Institute and State University, Department of Geological Sciences, Memoir 2, 329 p.

Editorial responsibility: Sandra M. Barr 
